\title{
Tradisi Keagamaan dan Proses Sosial pada Kaum Muslim Pedesaan
}

\author{
Agus Riyadi \\ Fakultas Dakwah dan Komunikasi UIN Walisongo Semarang \\ E-mail:agus.riyadi@walisongo.ac.id
}

\begin{abstract}
Religious ceremonies that are usually carried out by Javanese are inherited from the ancestors. There are two types of religious ceremonies in the form of salvation in Javanese society, namely life cycle salvation ceremonies and Islamic religious holidays. The research aims to find an understanding of the traditions of religious ceremonies and social processes for Muslims in Karangrayung District, Grobogan Regency. Data collection methods were obtained through observation, interviews, documentation and literature study. After that, the data is analyzed qualitatively-descriptive-interpretative. The results showed that there were seven religious ceremonies and social processes which until now were still commemorated by the Karangrayung people, namely: Sura (Muharam), Rajaban selametan, Mauludan selametan, Selametan Ruwahan, Selametan Likuran, Selametan Bodonan, and Selametan Besar which were held on the $10^{\text {th }}$ Zulhijjah. The perception of the people of Karangrayung on religious ceremonies and social processes is a form of virtue that is recommended by Islamic teachings that contain values: 1) charity, 2) ukhwah Islamiyah, 3) help, and 4) share with others.
\end{abstract}

Keywords: social processes; religious tradition; religious ceremony.

\begin{abstract}
ABSTRAK
Upacara keagamaan yang biasa dilakukan oleh masyarakat Jawa merupakan warisan nenek moyang. Ada dua jenis upacara keagamaan dalam bentuk selamatan di kalangan masyarakat Jawa, yaitu upacara selamatan siklus hidup dan upacara selamatan hari besar Islam. Penelitian bertujuan untuk mencari pemahaman tentang tradisi upacara keagamaan dan proses sosial
\end{abstract}


pada kaum muslim di Kecamatan Karangrayung, Kabupaten Grobogan. Metode pengumpulan data diperoleh melalui observasi, wawancara, dokomentasi dan studi kepustakaan. Setelah itu, data dianalisis secara kualitatif-deskriptif-interpretatif. Hasil penelitian menunjukkan bahwa ada tujuh upacara keagamaan dan proses sosial yang sampai saat ini masih diperingati oleh masyarakat Karangrayung yaitu : Sura (Muharam), selametan Rajaban, selametan Mauludan, selametan Ruwahan, selametan Likuran, selametan Bodonan, dan selametan Besaran yang dilaksanakan setiap tanggal 10 Zulhijjah. Adapun persepsi masyarakat Karangrayung terhadap upacara keagamaan dan proses sosial adalah merupakan suatu bentuk kebajikan yang dianjurkan oleh ajaran Islam yang mengandung nilai-nilai: 1) sedekah, 2) ukhwah islamiyah, 3) tolong menolong, dan 4) berbagi dengan sesama.

Kata Kunci : proses sosial; tradisi keagamaan; upacara keagamaan.

\section{Pendahuluan}

Risalah Islam disampaikan kepada manusia demi tercapainya kebahagiaan materiil dan spiritual. Islam membawa konsep-konsep pembangunan manusia seutuhnya dan sangat revolusioner dengan proses yang evolusioner. Sebagai agama dakwah, Islam mengajak manusia mengikuti ajaran dalam Al Quran dengan cara yang bijaksana, tutur kata yang baik, dan bertukar pikiran dengan jernih (QS. Asy Syu'araa': 125). Prinsip tersebut menegaskan bahwa penyebaran agama Islam harus dilakukan dengan mempertimbangkan situasi dan kondisi masyarakat yang bersangkutan, sebagimana banyak dicontohkan oleh Nabi Muhammad SAW, termasuk bagaimana bergumul secara rumit dengan budaya kejawen karena para raja telah memeluk agama Hindu dan masyarkat meyakini animisme dan dinamisme sebelum kedatangan agama Islam (Simuh 2003, 81).

Penyebaran Islam dengan cara damai juga dilaksanakan oleh Walisongo di Jawa. Islam datang ke negeri ini menghadapi masyarakat yang tidak kosong dari kebudayaan (Ali 1984, 25). Ketika datang, Islam harus memasuki situasi daerah yang mempunyai sistem politik religius dan sosial yang besar yang dibentuk oleh kerajaan-kerajaan besar HinduBudha yang telah berabad-abad menancapkan akar-akarnya(H. Geertz 1985, 33). Tetapi dalam waktu yang relatif singkat dan boleh dikatakan tanpa bantuan dan kekerasan, Islam telah tersebar di pulau Jawa (C. 
Geertz 1982, 16). Jalan damai ini telah menghasilkan suatu kebudayaan dengan nafas Islam salah satunya sebagaimana yang terlihat dalam upacara selamatan (C. Geertz 2013, 236).

Ada dua jenis upacara selamatan di kalangan masyarakat Jawa, yaitu upacara selamatan siklus hidup dan upacara selamatan hari besar Islam. Menurut Kodiran $(1984,41)$ upacara selamatan yang berakitan dengan siklus hidup meliputi selamatan kelahiran, perkawinan, kematian, kesembuhan dari penyakit, tolak balak, pindahan rumah atau mendapatkan anugerah, dan selamatan yang berkaitan dengan pertanian. Adapun upacara selamatan hari besar Islam pada masyarakat Jawa meliputi selamatan Suran yang dilaksanakan pada tanggal 10 Sura (Muharam), selamatan Rajaban yang dilaksanakan pada tanggal 27 Rajab namun kini sering digeser tanggal pelaksanaan, selamatan Mauludan yang dilaksanakan tanggal 12 Maulud, selamatan Ruwahan yang dilaksanakan pada tanggal 15 Sya'ban, selamatan Likuran yang dilaksanakan pada tanggal 21 bulan Ramadlan, selamatan Bodonan yang dilaksanakan pada tanggal 1 Syawal, dan selamatan Besaran yang dilaksanakan pada tanggal 10 Zulhijjah. Dengan demikian, masyarakat Jawa melaksanakan 7 kali selamatan yang berhubungan dengan hari raya Islam atau rata-rata setiap dua bulan sekali. Apabila ditambah dengan selamatan siklus hidup, masyarakat pedesaan rata-rata melaksanakan selamatan satu bulan sekali.

Salah satu daerah yang masih kental dengan pelaksanaan upacaraupacara di atas antara lain adalah Kecamatan Karangrayung, Kabupaten Grobogan. Dengan beragam komposisi masyarakat di dalamnya, sebagian besar masyarakat di daerah tersebut asih melaksanakan upacara selamatan dengan tujuan tertentu. Upacara dilaksanakan dengan cara setiap kepala keluarga diharuskan menyediakan ambengan atau sajian. Dalam pandangan masyarakat, semakin mewah sajian/ambengan maka akan mendapatkan penghargaan sosial yang tinggi. Berdasarkan pada pandangan tersebut, maka masyarakat cenderung berlomba-lomba dalam menyediakan ambengan baik dari segi kuantitas maupun kualitasnya. Studi pendahuluan yang dilakukan penulis menunjukkan bahwa biaya yang dikeluarkan oleh masyarakat Karangrayung dalam setiap upacara hari besar sekitar Rp.75.000 sampai Rp.100.000. 
Dengan besaran biaya selamatan tersebut, tentunya bisa mengurangi sumber dana untuk kebutuhan sosial lainnya. Hal tersebut bisa dilihat dari minimnya sumber dana untuk penghijauan lahan, perbaikan jalan, sarana pendidikan dan sarana dalam bidang kesehatan. Akibatnya sarana dan prasarana di masyarakat tidak banyak berkembang dari tahun ke tahun. Indikasinya adalah antara lain: 1) Sebagian besar jalan desa masih belum diaspal sehingga mengakibatkan rendahnya pertumbuhan ekonomi masyarakat. 2) Banyak gedung Sekolah Dasar (SD) atau Madrasah Ibtidaiyah (MI) yang kondisinya sangat memprihatinkan, bahkan ada yang hampir roboh. 3) Terbatasnya fasilitas kesehatan di masyarakat. Hal tersebut bisa dilihat dari minimnya jumlah tempat dan petugas kesehatan di masyarakat.

Berdasarkan uraian di atas, tampak jelas terjadi ketidakseimbangan antara pengeluaran dana masyarakat yang digunakan untuk keperluan selamatan dengan dana yang digunakan untuk keperluan peningkatan sarana dan prasarana masyarakat. Mereka lebih mengutamakan selamatan dari pada kepentingan sosial kemasyarakatan. Fenomena di atas menarik untuk diteliti. Dalam penelitian ini akan diambil sampel tiga desa di Kecamatan Karangrayung. Kecamatan tersebut merupakan daerah pinggiran yang sebagian besar penduduknya adalah petani (petani penggarap dan buruh tani). Sehingga mencerminkan prototipe muslim pedesaan yang berpenghasilan rendah. Agar sampel penelitian ini mewakili masyarakat Kecamatan Karangrayung pada umumnya, dipilih tiga desa yang memiliki tingkat sosial, ekonomi, dan pendidikan yang berbeda. Sebagaimana data monografi di Kecamatan Karangrayung, desa Welahan mewakili kelompok masyarakat tingkat ekonomi tinggi, desa Jetis mewakili kelompok tingkat ekonomi menengah, dan desa Nampu mewakili kelompok tingkat ekonomi rendah. Artikel ini bertujuan untuk mengetahui pelaksanaan tradisi keagamaan dan proses sosial pada kaum muslim di Kecamatan Karangrayung, Kabupaten Grobogan; dan persepsi masyarakat mengenai arti penting tradisi keagamaan dan proses sosial pada kaum muslim di Kecamatan Karangrayung, Kabupaten Grobogan. Secara teoritis, studi ini akan menjadi tambahan khasanah informasi di bidang lmu Dakwah dan Ilmu Antropologi agama khususnya tentang model penghayatan keagamaan masyarakat pedesaan. Sedangkan 
secara praktis, studi ini akan menjadi bahan masukan bagi para da'i dan pembina kehidupan agama dalam upaya meningkatkan peran agama dalam pembangunan.

Metode penelitian yang digunakan dalam penelitian ini adalah metode deskriptif kualitatif dengan pendekatan sosio-antropologis (Nata 2001, 35). Data yang dikumpulkan bersifat lapangan yang berwujud fenomena keagamaan. Sifat penelitian ini deskriptif-interpretatif, yaitu berusaha menggambarkan fakta dan kenyataan sosial kemudian dianalisis dengan mengunakan pengetahuan, ide-ide, konsep-konsep yang ada dalam upacara keagamaan. Untuk memperoleh data primer dan data sekunder, penulis menggunakan teknik observasi, wawancara, dokomentasi dan studi kepustakaan. Data yang telah terkumpul kemudian dilanjutkan dengan tahapan analisis data secara kualitatifdeskriptif-interpretatif. Analisis ini merupakan tahapan pengolahan, pengelompokan dan penjabaran data yang terkumpul sesuai dengan kebutuhan untuk menjawab permasalahan penelitian (Moloeng 1998, 190).

Secara historis, kebudayaan masyarakat Indonesia terbentuk dalam suatu cara berpikir yang kompleks, termasuk perasaan dan emosi yang terlibat di dalamnya. Oleh karena itu, rangkaian ritus, mantera, dan doa diperlukan untuk memeberikan kenyamanan dalam hati dan perasaan sehingga semua itu kemudian menjelma menjadi agama dalam masyarakat. Masyarakat Jawa menempatkan ritus dan budaya sebagai perwujudan agama sebagai realitas sosial (Simuh 2003, 42-44). Hal ini berimplikasi pada agama memberikan jawaban terhadap problematika psikologi dan yang membawa perdamaian yang akan menyemai kohesi sosial (Abdullah 2009). Keagamaan orang Jawa, pada dasarnya dimanifestasikan terhadap pemujaan nenek moyang. Nenek moyang adalah leluhur yang terdekat, leluhur tertentu dari masa lalu yang lebih jauh atau pencipta alam semesta yang dianggap sebagai sumber kekuatan hidup. Para leluhur itu dianggap terus mempengaruhi mereka yang masih hidup (C. Geertz 2013, 534). Oleh karena itu, suku Jawa mempunyai kekayaan simbolisasi yang terefleksikan dalam berbagai budayanya, salah satunya adalah adanya selametan atau upacara keagamaan. 
Upacara adalah rangkaian tindakan atau perbuatan yang terikat pada suatu aturan tertentu yang bersumber dari adat dan agama (Sofwan 2000, 130). Menurut (Beatty 1985, 412), upacara adalah sistem aktifitas rangkaian tindakan yang ditata oleh adat atau hukum yang berlaku dan berhubungan dengan berbagai macam peristiwa tetap yang terjadi dalam masyarakat. Upacara juga dapat diartikan suatu kegiatan pesta tradisional yang diatur menurut tata adat atau hukum yang berlaku di masyarakat dalam rangka memperingati peristiwa penting atau lain-lain dengan ketentuan adat yang berlaku pada masyarakat yang bersangkutan.

Singkatnya, upacara adalah bentuk rangkaian kegiatan dalam hidup bermasyarakat yang tindakannya terikat pada aturan agama maupun adat istiadat dalam bentuk acara makan bersama yang makanannya telah disucikan (diberi do'a) sebagai perwujudan rasa syukur atau rasa terima kasih kepada Tuhan serta didorong oleh hasrat untuk memperoleh ketentraman hati atau mencari keselamatan dengan tata cara yang telah ditradisikan oleh masyarakat.

Upacara keagamaan merupakan sarana komunikasi yang memuat pesan-pesan agama. Seperti yang dijelaskan oleh Suparlan (1981, 88) bahwa pesan dalam upacara itu sesuai dengan tujuan yang ingin dicapai oleh upacara tersebut dan sesuai pula dengan keinginan yang ada pada warga masyarakat yang bersangkutan.

Upacara selametan keagamaan juga memuat pesan-pesan agama yang bertujuan secara umum meningkatkan iman dan takwa kaum muslimin. Pesan-pesan yang dinyatakan lewat simbol-simbol pada satu upacara itu, tentulah berbeda dengan pesan yang dinyatakan oleh simbol-simbol pada upacara lainnya. Dengan simbol-simbol itu, maka apa saja yang diinginkan diharapkan menjadi kenyataan, sebagaimana dijelasan oleh Suparlan $(1981,88)$ :

Dalam upacara, simbol berperan sebagai penghubung antara sesama manusia dan antara manusia dengan benda, dan juga sebagai alat penghubung antara dunia yang nyata dengan dunia yang gaib. Hal-hal atau unsur-unsur yang gaib yang berasal dari dunia yang gaib menjadi nampak nyata dalam arena upacara berkat peranan berbagai simbol (baik yang suci maupun yang biasa). 
Secara detail pesan-pesan semangat iman dan takwa berkaitan dengan upacara keagamaan dinyatakan oleh simbol-simbol dalam selametan, sebagaimana yang dinyatakan oleh Jane Horrison (Turner 1974, 102), bahwa simbol-simbol dalam selametan itu meliputi apa yang dipertontonkan, apa yang dilakukan, dan apa yang diucapkan. Maka dalam selametan upacara keagamaan, makna-makna simbolnya dapat dilihat pada ketiga aspek itu.

Efektif tidaknya upacara keagamaan dan proses sosial, tergantung pada dipahami atau tidaknya makna simbol dan apa yang dikerjakan, apa yang dipertontonkan dan apa yang diucapkan oleh kaum muslimin itu sendiri. Bahwa sikap kaum muslimin di Kecamatan Karangrayung terhadap upacara selamatan itu sehingga mereka bersedia mengeluarkan biaya besar namun kurang berminat terhadap pengelolaan lingkungan dan kesehatan adalah tergantung pada bagaimana mereka menanggapi masalah itu. Le Vine (1973, 3-4) menyatakan bahwa pandangan manusia terhadap diri dan lingkungan kehidupan menggunakan jalan aturan yang ada dalam kebudayaannya. Dia menambahkan bahwa hubungan antar kegiatan manusia dan lingkungan hidupnya dijembatani oleh pola-pola kebudayaan yang dimiliki manusia (Suparlan 1983, 66). Dengan kebudayaan yang dimilikinya, maka manusia mempertahankan diri, bertahan dan memanfaatkan lingkungannya untuk mempertahankan kehidupannya.

Sementara itu, kebudayaan adalah keseluruhan pengetahuan manusia sebagai makhluk sosial yang dipergunakan untuk memahami dan menginterpretasikan lingkungan dan pengalamannya serta menjadi kerangka landasan dalam mewujudkan dan terwujudnya kelakuan (Suparlan 1981, 8). Definisi yang dirumuskan Suparlan ini menempatkan kebudayaan sebagai sistem atau konseptualisasi kelakuan. Dengan kebudayaan yang dimilikinya itu, manusia menggunakannya untuk memenuhi kebutuhan, kebutuhan akan upacara dan kebutuhan akan kesehatan dan lingkungan. Suparlan (1986, 9-10) membuat tiga klasifikasi kebutuhan. Pertama, kebutuhan pokok, yaitu kebutuhan yang bersumber pada aspek biologi, seperti: makan, minum, buang air, perlindungan cuaca iklim, istirahat. Kedua, kebutuhan sosial atau kebutuhan sekunder yang terwujud dalam hubungannya dengan 
manusia lain seperti: berkumpul, berkomunikasi, kegiatan-kegiatan bersama. Ketiga, kebutuhan integratif, yang muncul akibat manusia sebagai mahkluk berfikir seperti perasaan benar salah, adil dan tidak adil, baik buruk dan lain sebagainya, ungkapan estetika, perasaan keyakinan, rekreasi dan hiburan.

Berbagai ragam kebutuhan manusia yang harus dipenuhi mengakibatkan manusia memilih mana yang harus dipenuhinya. Jika harus memilih, salah satunya harus meletakkan prioritas jika ada beberapa kebutuhan yang harus dipenuhi. Pemilihan itu berdasarkan alternatif seperti pelaku bertindak dengan menekankan pentingnya lingkungan sesuai kebudayaannya; pelaku bertindak dengan menekankan pentingnya kebudayaan sesuai pentingnya kebutuhan-kebutuhan; pelaku bertindak dengan menekankan kebiasaan sesuai pemenuhan kebutuhan tanpa memperhatikan budayanya; pelaku menekankan pentingnya pengetahuan kebudayaan yang dimilikinya dalam rangka pemenuhan kebudayaannya; pelaku bertindak dengan menekankan pentingnya pengetahuan dan pemenuhan kebudayaan dan lingkungan; danpelaku bertindak dengan menekankan pentingnya kepuasan pemenuhan kebutuhan (Suparlan 1986, 13).

Tindakan kaum muslim Kecamatan Karangrayung dapat dilihat bagaimana meletakkan kebutuhan upacara dan kebutuhan lainnya. Oleh karena itu, kita harus melihat dari perkembangan kebudayaannya, pengetahuan budaya serta situasi lingkungannya.

Berdasarkan kerangka teori tersebut di atas maka dapat dikemukakan hipotesis deskriptif sebagai berikut, yang pertamakesadaran masyarakat kaum muslim Kecamatan Karangrayung untuk mengeluarkan biaya besar dalam upacara hari besar Islam dan kurang memandang penting kebutuhan pembangunan yang lain adalah disebabkan oleh penekanan terhadap pengetahuan budaya mereka tentang nilai pahala dalam upacara hari besar Islam, serta pengetahuan tentang makna ibadah.

Kedua, efektif tidaknya upacara hari besar Islam itu terletak pada dipahami tidaknya simbol-simbol dalam upacara, baik yang bersifat transformatif maupun seremonial, baik simbol yang diucapkan (do'a) simbol yang dipertontonkan (sarana upacara) dan simbol yang dikerjakan (tindakan-tindakan). Ketiga, besarnya biaya yang dikeluarkan 
oleh para pelaku upacara ditentukan juga oleh jenis upacara itu apakah transformatif atau konfermatif. Keempat, pengetahuan budaya para peserta upacara terhadap upacara hari-hari besar mempengaruhi persepsi mereka terhadap hakekat upacara.

\section{Hasil dan Pembahasan}

\section{A. Proses Upacara Keagamaan dan Proses Sosial di Kecamatan Karangrayung Kabupaten Grobogan.}

Berdasarkan data yang diperoleh dari hasil penelitian, pelaksanaan ritual keagamaan di wilayah Kecamatan Karangrayung pada umumnya selalu diperingati dalam bentuk selamatan dengan pembacaan do'a bersama. Seperti do'a Rajaban, do’a Suronan, do’a Mauludan, do’a Ruwahan, dan do'alainnya. Adapun proses pelaksanaan upacara keagamaan dan proses sosial di Kecamatan Karangrayung Kabupaten, Grobogan adalah sebagai berikut:

\section{Upacara Sura}

Upacara Suranan di kalangan masyarakat Kecamatan Karangrayung tidak dilaksanakan pada tanggal 1 atau 2 Muharram, tetapi pada tanggal 10 Sura. Upacara dibuka oleh Modin dengan tahlil pendek atau dzikiran dengan membaca kalimat syahadat dan shalawat dengan metode tertentu dan dilanjutkan do'a kepada Hasan-Husein. Setelah selesai, maka perangkat desa memberikan sambutan tentang masalah pembangunan yang dilaksanakan di desanya, instruksi dan pengumuman dari pemerintah.

Setelah sambutan perangkat desa selesai, maka jamuan dilaksanakan. Orang-orang terhormat di tingkat dukuh pada satu majlis tersendiri dan mereka makan bersama, sedangkan peserta upacara yang lain makan bawaan mereka. Jamuan makan ini dilaksanakan setelah dibacakan do'a dan penutup, setelah jamuan lalu selesai, peserta membubarkan diri.

Adapun biaya untuk upacara ini, tidak sebesar upacara hari besar Islam yang lainnya. Hal ini sebagaimana yang dikemukakan oleh Bapak Mugiono, sebagai berikut: 
"Upacara selamatan ini dilakukan setahun sekali pada tanggal 10 Sura yang ditempatkan di rumah modin, namun ada juga sebagian masyarakat yang melakukan upacara selametan ini bertempat di pertigaan atau perempatan jalan. Penyelenggaraan upacara ditangani oleh pejabat RT atau RW atas intruksi kepala desa (kelurahan). Peserta upacara ini terdiri dari masyarakat setempat mulai dari bapak-bapak, ibu-ibu, generasi muda, anak-anak. Pimpinan upacara ini adalah tokoh masyarakat setempat yang taat dan tahu agama Islam dan bisa membaca do'a secara bahasa Arab. Peralatan upacara yang lazim digunakan adalah nasi tumpeng dengan laukpauk ingkung ayam, ditambah dengan tahu tempe, kuluban, dan ikan laut. Bahan upacara tersebut didapat dari anggota masyarakat setempat yaitu setiap kepala keluarga ditarik sebesar Rp. 20.000,-. Disamping itu juga masyarakat disarankan untuk membawa tiga takir nasi, serta tiga takir lauk pauk yang terdiri dari tempe, daging ayam, pergedel, rempeyek, dan mie. Upacara untuk Sura ini tarikan tidak sebesar untuk kegiatan upacara yang lain seperti Isra' mijratan dan juga Mauludan” (Wawancara dengan Bapak Mugiono 6 Juni 2013).

Hal tersebut menunjukkan bahwa penyelenggaraan selamatan Sura yang dilakukan oleh masyarakat Kecamatan Karangrayung ini tidak begitu banyak mengeluarkan biaya bila dibandingkan dengan selamatan upacara-upacara hari besar yang lainnya.

\section{Upacara Maulud}

Upacara yang biasanya mengeluarkan biaya lebih besar adalah upacara Mauludan. Ini terjadi karena dalam upacara itu dilaksanakan dua kegiatan yang keduanya membutuhkan konsumsi yang cukup tinggi. Upacara pertama dilaksanakan di rumah modin dengan membawa nasi dan lauk pauk sebagaimana upacara yang dilaksanakan dalam upacara Suran. Prosedur dan tata caranya juga hampir sama dengan upacara Suran di ketiga kelompok masyarakat di Kecamatan Karangrayung. Upacara kedua dilaksanakan di masjid dan mushalla-mushalla. Hampir setiap mushalla apalagi masjid melaksanakan upacara peringatan Maulud Nabi. Jika di desa Jetis terdapat 15 Mushalla termasuk masjid maka upacara itu juga dilaksanakan pada 15 tempat di satu desa.

Umumnya peserta yang hadir pada upacara itu adalah anak-anak muda. Bagi yang laki-laki mengadakan upacara di mushalla dan bagi perempuan mengadakan upacara di tempat pengajian perempuan. Umumnya pengajian anak laki-laki diadakan lebih dahulu dari pada pengajian perempuan. Pada tiga kelompok masyarakat tersebut tidak ada 
perbedaan waktu pelaksanaannya, yaitu dilaksanakan pada malam hari sesudah salat Isya' dan biasanya sampai larut malam. Model pengajian laki-laki biasanya tepat dilaksanakan malam 12 Rabiul Awal tetapi kini lebih sering bergeser mundur karena menyangkut kesediaan pembicara. Untuk pengajian putri kadang dilaksanakan pada tanggal pertengahan antara tanggal 15 sampai dengan 20 dan kini pun lebih sering mundur karena alasan yang sama, yakni menyangkut kesediaan pembicara.

Upacara Mauludan diawali dengan acara khataman Al-Qur'an. Pada saat itu, keseniaan anak-anak juga ditampilka sesudah acara khataman Al-Qur'an. Lalu, acara dilanjutkan dengan mau'idhah hasanah oleh pembicara dari luar daerah. Pembicara tersebut menguraikan Maulud dan kehidupan agama pada umumnya. Ketika semua rangkaian acara selesai, maka dilaksanakan pembacaan al-Berjanzi sampai selesaidimana acara akan berakhir hingga jam satu dini hari baru selesai.

Ada beragam konsumsi yang disedikan pada acara tersebut. disamping toples yang berisi makanan ringan, ada juga buah-buahan dan telor yang ditontonkan. Menurut informasi dari Bapak Kusno, salah satu tokoh agama desa Jetis, biaya setiap kepala keluarga untuk upacara Mauludan baik di rumah Modin maupun di masjid lebih kurang adalah sebesar Rp. 75.000,--

\section{Upacara Rajab}

Upacara Rajaban merupakan upacara yang paling besar dari semua upacara hari besar keagamaan. Pelaksanaan upacara ini ada di bulan Rajab yang tanggalnya menyesuaikan dengan pembicaranya. Berbeda dengan upacara Mauludan yang dilaksanakan pada setiap masjid maupun mushalla, maka acara rajaban hanya dilaksanakan di masjid tingkat dukuh. Muabaligh yang paling kondang diundang bahkan kadang mendatangkan mubaligh dari luar Provinsi. Maka tidak mengherankan bila biaya yang diperlukan untuk acara ini cukup besar. Untuk memenuhi kebutuhan acara ini, setiap kepala keluarga akan ditarik iuran untuk biaya pembicara. Disamping itu, mereka juga harus menyediakan konsumsi paling sedikit untuk lima orang. Hal itu diperlukan karena jamaah warga dari desa lain pasti diundang untuk menghadiri acara tersebut. 
Di beberapa kelompok masyarakat desa, menyediakan konsumsi untuk peserta yang hadir hampir seperti perlombaan. Pada saat ini, orang-orang akan berlomba-lomba menunjukkan betapa mereka adalah dermawan. Di Desa Nampu misalnya, seorang peserta membawa nasi yang harus dibawa oleh empat orang, pada iyan (tempat mendinginkan nasi) yang besar di tengahnya terdapat opor angsa. Di sekeliling angsa ada telur asin yang jumlanya mencapai 30 butir. Di tiap ujung iyan ada selembar sarung yang total berjumlah empat buah. Di tiap ujung iyan itu ada bendera yang masing-masing terbuat dari uang lima ribuan.

Bapak Suparno, seorang tokoh masyarakat dari kelompok priyayi, menjelaskan sebagai berikut:

"Rata-rata per kepala keluarga mengeluarkan untuk peringatan Rajaban ini mengeluarkan Rp75.000,-. Sedangkan pada kelompok masyarakat desa, tidak kurang dari Rp 100.000,-. Hal ini dikarenakan kerukunan masyarakat desa masih terbangun secara baik. Bahwa masyarakat desa bila mau mengeluarkan ambengan atau tumpeng yang sangat besar dia beranggapan akan mendapatkan pahala yang lebih besar" (wawancara pada tanggal 6 Juni 2013).

Berdasarkan pada hasil wawancara di atas, dapat disimpulkan bahwa, komunitas masyarakat kecamatan Karangrayung, khususnya masyarakat desa memiliki pemahaman bahwa semakin banyak mereka beramal, maka akan semakin besar pahala yang akan didapatkannya.

\section{Upacara Ruwah}

Pelaksanaan upacara selametan ruwahan di kalangan masyarakat muslim Kecamatan Karangrayung dilaksanakan pada tanggal 15 Ruwah malam. Ketika salat Maghrib selesai dikerjakan, kaum muslimin bergegas menuju masjid atau mushalla dengan membawa Al-Qur'an atau Surat Yasin. Pada saat ruangan sudah penuh, Bapak Kyai segera mengambil tempat dan memimpin upacara untuk membaca Surat Yasin tiga kali. Kyai tersebut akan memulai upacara dengan khutbah pendek beliau menyatakan bahwa Nisfu Sya'ban adalah saat dibukanya lembaran baru bagi catatan amal manusia. Jama'ah duduk dan mendengarkan khutbah pendek tersebut dengan khusuk. Pembacaan Surat Yasin pertama dimulai setelah hadirin (jama'ah) dibimbing membaca niat mohon kepada Allah SWT agar ditetapkan iman dan Islamnya. Setelah bacaan pertama 
selesai, mereka memohon agar Allah SWT memberikan usia yang panjang dan diteruskan dengan bacaan Yasin yang ke dua. Kemudian hadirin (jama'ah) dibimbing untuk permohonan yang ke tiga yaitu agar dimudahkan rizki serta terkabul keinginannya, dilanjutkan dengan bacaan Yasin yang ketiga.

Selesai membaca Surat Yasin tiga kali, waktu Isya' tiba dan semua jamaah kemudian mengikuti Sholat Isya' berjama'ah setelah itu mereka membubarkan diri. Ketika waktu menunjukkan pukul12.00 malam, beberapa orang datang lagi untuk bersama-sama menjalankan salat Tasbih, salat yang di dalamnya banyak mensucikan Allah SWT.

\section{Upacara Likuran}

Upacara Likuran yang dilaksanakan pada tanggal 21 Ramadlan bertujuan untuk memperingati malam Lailatul Qadar. Upacara ini dilaksanakan di masjid maupun di mushalla setelah salat tarawih. Konsumsi dan tata cara pelaksanaan acara ini adalah seperti upacara selametan Suran. Beberapa dukuh tidak lagi melaksanakan upacara ini karena dianggap kurang efektif. Biaya untuk upacara Likuran ini menurut hasil wawancara dengan salah satu tokoh masyarakat, bapak Mahmud, adalah dimana setiap keluarga mengeluarkan biaya sebesar Rp. 20.000.hingga 25.000.-

\section{Upacara Bodonan / Syawal}

Upacara Bodonan dilaksanakan di hampir setiap masjid. Kaum muslimin melaksanakan upacara ini pada waktu yang bersamaan yakni tanggal 1 Syawal. Setiap kepala keluarga membawa konsumsi dengan lauk-pauk yang mewah untuk 5 (lima) orang. Setelah khutbah Idul Fitri, lima orang berkumpul untuk menghadapi satu porsi. Biasanya orang yang hadir menikmati ambengan tidak dari yang dibawanya. Pada selametan ini setiap keluarga mengeluarkan lebih kurang Rp. 75.000.sampai dengan Rp.100.000.-

Dalam berbagai catatan, masyarakat Jawa umumnya mengenal dua kali pelaksanaan lebaran, yaitu Idul Fitri dan lebaran ketupat. Idul Fitri dilaksanakan tepat pada tanggal 1 Syawal, sedangkan lebaran ketupat adalah satu minggu setelahnya (7 Syawal). 
Tradisi lebaran ketupat diselenggarakan pada hari ketujuh bulan Syawal setelah menyelesaikan puasa Syawal selama 6 hari. Pada hari itu, masyarakat muslim Jawa umumnya membuat ketupat, yaitu jenis makanan yang dibuat dari beras yang dimasukkan ke dalam anyaman daun kelapa (janur) yang dibuat berbentuk kantong, kemudian dimasak. Setelah masak, ketupat tersebut diantar ke kerabat terdekat dan kepada mereka yang lebih tua, sebagai simbol kebersamaan dan lambang kasih sayang.

Adapun mengenai pelaksanaan selamatan kupatan, masyarakat muslim pedesaan Kecamatan Karangrayung melaksanakannya pada hari ke-7 di bulan Syawal pada pagi hari setelah sholat subuh sekitar jam 06.00 Wib. Pada pelaksanaan selametan ini, masyarakat membawa ketupat beserta sayur dan juga lepet ke masjid maupun musholla untuk mengadakan selamatan. Setelah selesaian berdo'a maka masayarakat melakukan makan bersama dengan cara saling bertukar ketupat dan sayur yang dibawanya.

\section{Upacara Besaran}

Upacara Besaran dilaksanakan di tempat yang berbeda, ada yang di masjid dan ada yang di mushalla. Upacara ini dilaksanakan pada tanggal 10Zulhijjah. Prosesnya sama dengan upacara Bodonan. Sesudah Khutbah Idul Adha selesai, para peserta menghadapi konsumsi yang disediakan bagi empat atau lima orang. Pada selametan ini besaran konsumsi untuk setiap kepala keluarga kurang lebihnya adalah Rp. 50.000,- sampai dengan Rp. 70.000.-

Pada Upacara Bodonan, Besaran, dan Likuran, ada beberapa dukuh yang sudah tidak merayakan upacara tersebut dikarenakan sekarang banyak para jama'ah sesudah melaksanakan salat Idul Fitri maupun salat Idul Adha secara berjama'ah dan langsung pulang setelahnya.

Di kalangan muslim pedesaan di Kecamatan Karangrayung, banyak upacara-upacara keagamaan yang diperingati dengan meriah dan dengan berbagai model prosesi yang mengeluarkan banyak biaya,. Namun masih ada lagi upacara yang tak kalah meriahnya dengan upacara keagamaan yaitu upacara bersih desa. 


\section{B. Persepsi Masyarakat terhadap Arti Penting Upacara Keagamaan dan Proses Sosial}

Dalam pelaksanaan upacara keagamaan dan proses sosial, terdapat makna spiritual baik dari segi positifnya maupun dari segi negatifnya. Di balik makna upacara keagamaan atau selametan terdapat tujuan yang harus diketahui oleh pelaksana atau pelaku upacara keagamaan tersebut. Pandangan mengenai maksud dan tujuan upacara keagamaan dan proses sosial dari beberapa orang yang diwawancarai adalah sebagai berikut:

Menurut Bapak Kusno, salah satu tokoh masyarakat, maksud dan tujuan diadakannya upacara selamatan keagamaan adalah sebagai berikut:

"Untuk melestarikan nilai-nilai budaya yang telah diwariskan oleh nenek moyang mereka sejak dahulu hingga sekarang. Oleh karena itu perlu dilestarikan dan dipelihara keaslian budaya maupun nilai-nilai budaya. Adapun tujuan dari upacara keagamaan atau selametan adalah merupakan rasa syukur atas nikmat yang diberikan oleh Allah yaitu yang berupa kesehatan dan juga rizki yang berupa hasil panen yang mereka peroleh dan mengharapkan tepat tinggalnya aman tentram terhindar dari berbagai macam bahaya atau malapetaka yang akan menimpa desanya. Walaupun masih ada cara-cara yang bertentangan dengan syariat Islam, dan itu dikembalikan pada diri masing-masing serta keyakinan masing-masing individu" (Wawancara dengan Bapak Kusno 29 Juni 2013).

Menurut kepala desa Jetis, tujuan upacara keagamaan atau selametan adalah sebagai berikut:

"Sebagai sarana untuk mempererat hubungan silaturahmi, membantu sesama muslim, mempererat persaudaraan, saling mendo'akan sesama muslim. Acara selametan merupakan kegiatan yang positif karena mengandung unsur ibadah. Dan selametan ini suatu kebiasaan yang sering dilakukan oleh masyarakat dahulu yang percaya pada hal-hal yang ghaib dan bersifat mistik, dikarenakan kurangnya daya pengetahuan sehingga meraka percaya kepada hal-hal seperti itu. Sedangkan inti dari upacara keagamaan atau selamatan adalah untuk upaya lebih menghargai dan menghormati warisan budaya yang telah diwariskan oleh leluhurnya. Upacara keagamaan atau selametan itu sudah mengalami peralihan dari budaya Hindu dengan budaya Islam apalagi sekarang orang yang memimpinnya juga oleh kyai yang ada di daerah setempat" (Wawancara dengan Kepala desa Jetis Bapak Burhanudin 29 Juni 2013).

Adapun menurut Bapak Ahmad Dahlan, tujuan upacara keagamaan dan juga selamatan adalah sebagai berikut: 
"Untuk mendekatkan diri dengan penguasa alam atau penciptannya yaitu Allah SWT. yang telah memberikan karunia dan rahmat-Nya kepada masyarakat Desa Jetis yang berupa tanah yang subur dan makmur di dalam pertaniannya sehingga menghasilkan khususnya padi sangat bagus dan memuaskan. Dan juga negatifnya kurang cocok dengan budaya Islam karena dengan proses upacaranya dikarenakan hal ini dilaksanakan oleh masing-masing individu sehingga dalam prakteknya banyak yang berbedabeda tergantung orangnya, sehingga menimbulkan kemusyrikan yang percaya kepada selain Allah SWT oleh karena itu keimanan yang ada harus diikuti oleh keyakinan yang ada pada diri kita, sehingga upacara tersebut bukan upacara sembahan kepada Dewi Sri melainkan upacara syukuran atas karunia dan nikmat yang telah Allah berikan kepada seluruh warga desa Jetis dan sekitarnya”. (Wawancara dengan Bapak Bapak Ahmad Dahlan, tanggal 29 Juli 2013).

Sebagian besar masyarakat Karangarayung menyatakan bahwa tujuan membuat tumpeng dan menyajikan hidangan pada upacara selamatan adalah untuk menjamu tamu atau menghormati tamu undangan. Hal itu sudah menjadi tradisi bahwa apabila kita mengadakan selamatan, sebagai ucapan terima kasih kepada para tamu yang diundang adalah dengan memberikan hidangan pada saat acara sudah selesai dan untuk dibawa pulang. Selain itu, ada juga masyarakat yang menyatakan bahwa tujuan dari penyajian hidangan pada saat selamatan adalah untuk bersedekah.

Hal ini sesuai apa yang diungkapkan oleh Bapak Supardi:

"Saya membuat tumpengan dan juga memberikan hidangan kepada para tamu ini adalah bertujuan untuk bersodaqoh dan juga menghormati tamu. Adapun pemberian berkat yang dibawa pulang setelah acara selesai ini adalah sudah menjadi tradisi masyarakat di sini" (Wawancara dengan Bapak Supardi tanggal, 6 Juli 2013).

Selametan adalah salah satu bentuk peneterasi budaya sekaligus media perantara dalam rangka menyampaikan Islam kepada masyarakat Hindu-Budha. Selametan-selametan ini tentunya merupakan media dakwah yang sangat efektif pada masa lampau.

Pada masa lalu ada tiga macam pendukung yang menyebabkan selametan mempunyai kedudukan yang kokoh. Pertama, sistem administrasi desa yang mengatur adanya bulu bekti (upeti atau persembahan), yang merupakan warisan masa kolonial, dimana pejabat desa mendapatkan bulu bekti dari rakyat. Dalam selametan, para peserta upacara membawa pulang sebagian makana dari makanan yang disajikan pada saat upacara. Makanan ini juga dibagikan kepada lurah dan pamong 
lainnya dengan kadar kuantitas yang bertingkat menurut tingkatan jabatannya. Sistem bulu bekti ini merupakan kebiasaan feodal atau penjajahan di mana rakyat tidak mungkin melawannya, tercermin dalam selametan hari besar Islam (selametan umum). Kedua, karena faktor sosial ekonomi. Masyarakat menganggap perlu diadakannya upacara selamatan dan mereka merasa senang dengan adanya selametan karena selametan merupakan kesempatan bagi mereka untuk makan enak. Ketiga, adanya dukungan dari para pemimpin agama pada saat itu yang memandang selametan sebagai media dakwah.

Selain tiga faktor diatas, ada beberapa nilai yang terkandung dalam upacara keagamaan dan proses sosial maupun selametan yang lainnya. Adapun nilai-nilai tersebut adalah:

\section{Nilai Sedekah}

Makanan dan minuman yang dihidangkan di dalam berbagai bentuk ritus, di masyarakat Jawa sering kali disebut selamatan, yang merupakan inti dari pelaksanaan suatu ritual. Selamatan bermanfaat memberikan keselamatan diri dari bahaya atau siksaan (So'an 2002, 153). Selamatan yang dilakukan pada saat upacara keagamaan maupun proses sosial yang lainnya, menurut sebagian masyarakat Karangrayung, merupakan suatu bentuk kebajikan yang dianjurkan oleh Islam. Kebaikan tersebut disebut sedekah, dimana dari pemberian sedekah tersebut akan diperoleh pahala yang akan sampai kepada yang melaksanakan selamatan maupun orang yang dikirimi do'a.

\section{Nilai Ukhwah Islamiyah}

Nilai $u k h w a h$ islamiyah dalam tradisi selamatan upacara keagamaan dan proses sosial pada masyarakat Karangrayung terdapat pada berkumpul dan bertemunya berbagai elemen masyarakat pada saat upacara diselenggarakannya. Dalam masyarakat Karangrayung, selamatan upacara keagamaan dan proses sosial memberikan kesempatan berkumpulnya sekelompok orang untuk berdo'a bersama, makan bersama (selamatan) secara sederhana, dimana kegiatan tersebut merupakan suatu sikap sosial yang mempunyai makna meningkatkan nilai ukhwah islamiyah terhadap sesama masyarakat. Di samping itu, 
selamatan juga menjadi media untuk memupuk ikatan persaudaraan diantara mereka.

\section{Nilai Tolong-menolong}

Kegiatan tolong-menolong pada orang yang mempunyai hajat, biasanya dilakukan oleh seseorang dengan penuh kerelaan, tanpa perhitungan akan mendapat pertolongan kembali, karena menolong orang yang punya hajat didasarkan pada rasa kebersamaan yang universal dalam jiwa makhluk manusia. Dasar dari tolong-menolong adalah perasaan saling butuh membutuhkan, yang ada dalam jiwa warga masyarakat (Koentjaraningrat 1985, 165). Nilai tolong-menolong dalam tradisi masyarakat Karangrayung terlihat ketika tetangga punya hajat. Misalnya hajat ketika tetangga sedang mendirikan rumah, dan perayaan pernikahan. Ketika perayaan pernikahan, ibu- ibu (para tetangga dan kerabat dekat) membantu dalam mempersiapkan hidangan (makan, minuman) untuk tamu undangan. Bahkan pada ketika pelaksanaan hajatan selesai, mereka bersama-sama membersihkan tempat-tempat yang telah digunakan. Dalam tolong-menolong, terdapat hubungan saling ketergantungan sebagai akibat dari adanya proses pertukaran dan pemberian balasan atas jasa yang diberikan orang lain kepada dirinya (Rudi 2013, 4). Pada masyarakat Karangrayung, kebiasaan saling tolongmenolong terjadi secara spontan dan suka rela, tetapi juga ada yang didasarkan pada perasaan saling membutuhkan yang ada dalam jiwa masyarakat tersebut.

\section{Berbagi dengan sesama}

Dalam upacara keagamaan dan proses sosial pada masyarakat Karangrayung terdapat nilai kearifan lokal berupa tradisi berbagi dengan sesama, sebagaimana tercermin dalam simbol acara berkatan. Masyarakat dengan berbagai latar belakang yang plural, baik yang kaya maupun yang miskin semua berbagi dengan sesama. Hal ini dilakukan sebagai ungkapan rasa syukur dan tanda terimakasih kepada Tuhan atas apa yang telah dilimpahkan kepada masyarakat.

Selain itu, terdapat juga dua unsur dakwah pokok yang terdapat dalam simbol-simbol selametan upacara keagamaan itu. Pertama, simbol 
perbuatan (what is done) yaitu kegiatan tukar-menukar, dimanasetiap peserta upacara keagamaan menyerahkan uang receh menurut kerelaannya dan mereka semua mendapatkan makanan yang terdiri dari kue ketan, pisang raja, kue apem, dan serabi yaitu makanan yang dibuat dari beras. Benda-benda ini merupakan simbol pokok dari simbol yang ditampilkan. Kedua, adalah simbol upacara (what is said) yang terdiri dari ucapan tahlil pendek dan do'a. Semua simbol ini berisi pesan tentang iman dan takwa serta mendo'akan arwah kaum muslimin serta memohon keselamatan.

Bagi masyarakat Karangrayung, mereka mempunyai tanggapan yang berbeda-beda terhadap selametan upacara keagamaan dan proses sosial sesuai dengan referensi yang mereka gunakan. Hampir keseluruhan responden menyatakan bahwa kegiatan selametan dalam upacara keagamaan dan proses sosial ini merupakan kegiatan keagamaan yang memang harus diperingati. Dalam penelitian ini ditunjukkan bahwa pengetahuan agama mempunyai pengaruh yang sangat besar terhadap keberadaan selametan dalam upacara keagamaan hari besar Islam maupun proses sosial.

Ternyata pendidikan umum tidak mempunyai pengaruh terhadap pandangan keagamaan mereka, baik yang berpendidikan tinggi maupun yang berpindidikan rendah. Ini dapat ditunjukkan bahwa mereka yang percaya pada Betara Kala (dalam upacara ngeruwat) justru dipercayai oleh sebagian para priyayi yang pendidikannya relatif lebih tinggi. Sebaliknya seorang yang buta huruf yang sering mengikuti pengajian menyatakan bahwa ngeruwat bisa membahayakan iman jika dipercayai. Sedangkan golongan priyayi yang terdidik sebagian menyakini bahwa jika ngeruwat tidak dilaksanakan, maka anak tunggal itu bisa celaka. Maka dalam hal ini jelas bahwa masyarakat yang tidak mengeyam pendidikan, tetapi rutin mengikuti pengajian mempunyai pengaruh yang sangat nyata terhadap kenyakinan keagamaan.

Selametan dalam upacara keagamaan hari besar Islam dan proses sosial menempati kedudukan yang penting dalam kehidupan keagamaan masyarakat Karangrayung terbuktinya dengan ada 73,3\% orang menyatakan bahwa itu merupakan kegiatan keagamaan. Selain itu, selametan Ruwahan itu masih efektif dalam meningkatkan iman 
dan takwa karena sebagian besar responden masih aktif melaksanakan upacara selametan karena itu merupakan bagian dari ibadah. Akan tetapi, hal yang perlu diingat adalah bahwa yang dinilai tinggi itu bukanlah selametannya, melainkan peristiwanya, yang oleh semua pihak dianggap sebagai peristiwa keagamaan. Ini dapat diketahui karena sebagian besar responden menyetujui agar selametan ini tidak perlu diadakan dengan persiapan makanan yang begitu spesifik, melainkan dengan konsumsi seadanya saja, sebab yang penting itu bukan makanannya melainkan pengisian rohaniahnya.

Persepsi demikian ini tidak lepas dari kenyataan bahwa penyediaan makanan bukan lagi merupakan masalah yang penting, sebab maknamakna yang ditampilkan (what is shown) sebagian besar tidak lagi dipahami. Kalaupun makna itu dipahami, nilainya tidak seefektif dengan simbol yang diucapkan.

Terdapat variasi dalam merayakan upacara keagamaan hari besar Islam di kalangan umat Islam Karangrayung. Upacara Maulud dan Rajab merupakan upacara yang dilaksakan secara meriah, di bawahnya adalah upacara Ruwahan, Suranan, dan Besaran, adapun upacara yang mulai ditinggalkan adalah Likuran. Secara metodis hanya ada dua hari besar yang nampaknya akan tetap dirayakan secara meriah yaitu upacara Mauludan dan Rajaban.

Jika dilihat sekarang ini, perkiraan biaya yang dikeluarkan untuk peringatan upacara keagamaan hari besar Islam berdasarkan data lapangan cukup beragam, Yang pertama, adalahuntuk hari raya yang selalu dimeriahkan dan selalu dilaksanakan setiap kelompok masyarakat yakni Mauludan dan Rajaban. Jumlah Kepala Keluarga di Kecamatan Karangrayung adalah 18.618 jiwa dan untuk masing-masing hari besar itu dikeluarkan rata-rata Rp. 75.000,-. Maka biaya yang dikeluarkan adalah 2 x $18.618 \times$ Rp. $75.000,-=$ Rp. 2.792.700.000. Kedua, adalahuntuk hari raya yang dilaksanakan sederhana dan sudah ada beberapa desa yang tidak melaksanakannya yakni Suranan, Ruwahan, Badanan, dan Besaran. Setiap selamatan, biaya selamatan Suran adalah Rp. 70.000, Ruwahan sebesar Rp. 100.000, Badanan sebesar Rp. 75.000, dan selamatan Besaran sebesar Rp. 20.000. Maka total biayanya adalah 18.618 x 70.000,- x 100.000,- x 75.000 x Rp. 20.000,- = Rp. 4.933.770.000,-. Ketiga adalah 
untuk hari besar yang sudah sebagian besar ditinggalkan yakni Likuran. jika tiap Kepala Keluarga mengeluarkan biaya sebesar Rp. 25.000,- maka biaya keseluruhan adalah $18.618 \times 25.000,-=$ Rp. 465.450.000.

Pemahaman sebagian masyarakat bahwa ibadah vertikal (kesalehan individual) lebih tinggi dari kesalehan sosial mendorong tetap dilaksanakannya upacara hari besar Islam dengan biaya tinggi. Hal ini karena nilai-nilai yang terkandung dalam upacara keagamaan telah menjadi proses sosial yang sangat kuat dan mengakar dalam masyarakat setempat. Artinya proses sosial sebagai pengaruh timbal-balik antar pelbagai segi kehidupan bersama, misalnya saling mempengaruhinya segi sosial dengan politik, politik dengan ekonomi, ekonomi dengan hukum, dan sebagainya.

\section{Kesimpulan}

Berdasarkan hasil dan pembahasan maka kesimpulan dari penelitian ini adalah adalah bahwa masyarakat Karangrayung adalah masyarakat santri yang sebagian kecil masih mempercayai praktek keagamaan warisan dari sejarah peng-Islaman di Jawa. Mereka masih sangat menghormati upacara hari besar Islam dengan menyediakan makanan pada setiap upacara. Ada tujuh macam upacara hari besar Islam yang sampai kini masih dilaksanakan yakni Suranan, Mauludan, Rajaban, Ruwahan, Lukuran, Badanan dan Besaran. Adapun untuk pelaksanaan dari masingmasing upacara hari besar Islam itu ada yang sama dan ada yang beda menurut kelompok sosial masing-masing. Di samping itu terdapat variasi dalam pengeluaran biaya untuk melaksanakan peringatan hari besar Islam. Pertama, ada hari besar Islam yang dilaksanakan secara meriah (dengan biaya besar) ada yang dilaksanakan biasa saja (dengan biaya yang tidak begitu besar) dan ada yang dilaksanakan secara sepi (dengan biaya kecil). Berdasarkan perhitungan dengan data lapangan tidak kurang dari 1 milyar selalu dikeluarkan oleh masyarakat Karangrayung setiap tahunnya dalam memperingati hari besar Islam. Kedua, hampir keseluruhan masyarakat Karangrayung menyakini bahwa memperingati upacara hari besar Islam dan proses sosial merupakan tugas agama, dan itu merupakan ibadah. Peringatan hari besar Islam dan proses sosial adalah sarana yang efektif bagi pembinaan dan peningkatan iman dan takwa kaum muslimin. Namun ada juga pemikiran pada sebagian masyarakat untuk mengadakan modifikasi 
dalam cara memperingati hari besar Islam yakni tidak perlu dengan disertai penyediaan makanan yang memerlukan biaya tinggi, tetapi lebih menekankan pada pembinaan rohaninya. 


\section{DAFTAR PUSTAKA}

Abdullah, Taufik. 2009. "Di Sekitar Masalah Agama Dan Kohesi Sosial: Pengalaman Dan Tantangan.” Jurnal Agama dan Masyarakat 11(1). http://jmb.lipi.go.id/index.php/jmb/article/view/232.

Ali, A. Mukti. 1984. "Penelitian Agama (Suatu Pembahasan Tentang Metode Dan Sistem).” Al-Jamiah: Journal of Islamic Studies (31). http://digilib.uin-suka.ac.id/480/.

Beatty, Suyono. 1985. Kamus Antropologi. Jakarta: Akademi Prasendo.

Geertz, Clifford. 1982. Islam Yang Saya Amati (Perkembangan Di Maroko Dan Indonesia). Jakarta: Yayasan IlmuIlmu Sosial.

-----.2013. Agama Jawa: Abangan, Santri, Priyayi Dalam Kebudayaan Jawa. Depok: Komunitas Bambu.

Geertz, Hildred. 1985. Keluarga Jawa. Jakarta: Grafiti Pers.

Kodiran. 1984. Masalah-Masalah Sosial Dan Ilmu Sosial Dasar, Bahan Bacaan Pelajar. Jakarta: Departemen Pendidikan dan Kebudayaan.

Koentjaraningrat. 1985. Beberapa Pokok Antropologi Sosial. Jakarta: Dian Rakyat.

LeVine, RA. 1973. Cultur and Personality. Chicago: Aldine.

Moloeng, Lexy J. 1998. Metodologi Penelitian Kualitatif. Bandung: Rosdakarya.

Nata, Abuddin. 2001. Metodologi Studi Islam. Jakarta: Raja Grafindo Persada.

Rudi. 2013. Studi Perbandingan Pranata Sosial. Bandung: http://blogs. unpad.ac.id. http://blogs.unpad.ac.id.

Simuh. 2003. Islam Dan Pergumulan Budaya Jawa. Jakarta: Teraju.

So'an, Sholeh. 2002. Tahlilan: Penelitian Historis Atas Makna Penelitian Indonesia. Bandung: Agung Ilmu.

Sofwan, Ridin. 2000. "Interelasi Nilai Jawa Dan Islam Dalam Aspek Kepercayaan Dan Ritual". Dalam M. Darori Amin, Islam Dan Kebudayaan Jaw. Yogyakarta: Gama Media. 
Suparlan, Parsudi. 1981. Pengetahuan Budaya, Ilmu-Ilmu Sosial Dan Pengkajian Masalah-Masalah Agama. Jakarta: Proyek Penelitian Keagamaan, Badan Litbang Agama, Depag RI.

-----. 1983. Kata Pengantar Dalam Clifford Geertz, Abangan, Santri Dan Priyayi Dalam Masyarakat Jawa. Jakarta: Pustaka Jaya.

-----. 1986. Kebudayaan Dan Pembangunan. Jakarta: Departemen Pendidikan dan Kebudayaan RI.

Turner, Victor. 1974. The Forest of Symbol. London: Cornell University Press. 